\title{
Testing of Two Varieties of Lupin Seeds as Substitutes for Soya Extracted Meal in Vegetable Diets Designed for Young Broilers
}

\author{
P. SUCHÝ, E. STRAKOVÁ, V. VEČEREK, V. ŠERMAN ${ }^{1}$, N. MAS ${ }^{1}$ \\ University of Veterinary and Pharmaceutical Sciences Brno, Czech Republic \\ ${ }^{1}$ Veterinarsky fakultet sveučilišta u Zagrebu, Hrvatska \\ Received March 6, 2006 \\ Accepted June 30, 2006
}

\begin{abstract}
Suchý P., E. Straková, V. Večerek, V. Šerman ${ }^{1}$, N. Mas ${ }^{1}$ : Testing of Two Varieties of Lupin Seeds as Substitutes for Soya Extracted Meal in Vegetable Diets Designed for Young Broilers. Acta Vet. Brno 2006, 75: 495-500.

The main aim of this experiment was to verify the suitability of two Polish varieties of dehulled lupin seed (the low-protein SONET variety and the high-protein JUNO variety) as protein components to replace $50 \%$ of soya extract meal in feeding mixtures designed for the feeding of young broilers. The results of this experiment demonstrate that suitable treatment of lupin seed (dehulling) may significantly increase its nutritional value. Dehulling provides a product (core) in which the level of nitrogen-containing substances is by $27 \%$ higher than that in the original seed, providing an important protein component to be added in feeding mixtures for chickens. The experiment has also shown that production performance depends on the particular Lupinus variety used. Chickens fed on the JUNO variety seed (Group E1) reached a live weight of $2.332 \mathrm{~kg}$ on Day 40, which is comparable with the control group of chickens (2.337 kg; Group C). However, chickens in Group E2 fed on the SONET variety seed had a conclusively lower average weight $(2.280 \mathrm{~kg})$ $(P \leq 0.05)$. Feed consumption per $\mathrm{kg}$ of weight gain at this level of average live weight was as follows: $1.89 \mathrm{~kg}$ (Group C), $1.85 \mathrm{~kg}$ (Group E1), and $1.93 \mathrm{~kg}$ (Group E2). The results confirm the suitability of dehulled lupin seed as a substitute for soya extract meal. When designing the composition of feeding mixtures one has to know the exact nutritional composition of the particular lupin variety. One important finding from a nutritional point of view is that the seed of the Lupinus genus is a major source of the amino acid arginine, which is often deficient in the feeding mixtures.
\end{abstract}

Growth of chickens, Lupin seeds, JUNO variety, SONET variety, performance

In connection with the ban on the use of meat-and-bone meal in animal feeds and with the increasing share of vegetable components in diets designed for farm animals, research is currently focusing on the development of new feeds, particularly protein-based feeds, to substitute meat-and-bone meal in traditional diets. Efforts are being made due both to economic and social perspective to either fully or at least partially replace soya beans and soya bean products (soya extract meals) with domestic (European) protein feeds. The seed of the Lupinus genus as one of the European cultural plants represents a promising alternative in this respect. The seed of some lupin varieties contains almost $50 \%$ nitrogenous substances, making lupin seed a potentially useful high-protein feed.

The potentially advantageous use of lupin seeds in feeding mixtures designed for young broilers is discussed in studies by Gualtieri and Rapaccini (1990), Teixiera and Dos (1995) and Roth-Maier and Paulicks (2003). Non-starch polysaccharides contained in the seed may, however, pose some problems from a dietetic point of view by increasing the viscosity of intestinal content (Kocher et al. 2000) and elevating water content in droppings, as reported by Farrell et al. (1999). This problem can be overcome by supplementing the feeding mixture with some enzymes, as reported by RothMaier and Kirchgessner (1995), Gdala (1998), Brenes et al. (2003), Steenfeldt et al. (2003)

Address for correspondence:

Prof. MVDr. Ing. Pavel Suchý, CSc.

Ústav výživy, zootechniky a zoohygieny

Veterinární a farmaceutická univerzita Brno

Czech Republic
Tel.: +420541562670

Fax: +420541562675

E-mail: suchyp@vfu.cz

http://www.vfu.cz/acta-vet/actavet.htm 
and Mieczkowska et al. (2004). Another important fact to consider is that from a nutritional point of view the levels of some of the essential amino acids in lupin seed are lower than those in soya meal (e. g. methionine, lysine, tryptophan). This is documented in studies by Perez-Alba et al. (1990), RothMaier and Kirchgessner (1993), Lettner and Zollitsch (1995), and Ravindran et al. (2002). Deficient amino acids can be added in the form of identical synthetic compounds.

Uziebo et al. (1996) has shown that some alkaloids associated with bitter lupin varieties may act as anti-nutritional factors. Therefore, most experiments are carried out using sweet lupin varieties, which are more likely to be used in animal nutrition than bitter varieties. The majority of the above-described dietetic problems can be successfully overcome if lupin seed is dehulled. A number of authors, e.g. Smulikowska et al. (1995), Annison et al. (1996), Rubio et al. (1998), Gdala (1998), Rubio et al. (2003) and Mieczkowska et al. (2005), reported a positive effect of treatment of lupin seed by dehulling. Furthermore, in the case of some lupin varieties dehulling provides a product (core) of a considerably higher nutritional value, which can be used to replace soya extract meal, as proven by some authors, e. g. Koreleski et al.(1987), RothMaier and Kirchgessner (1994) and Lettner and Zollitsch (1995).

\section{Materials and Methods}

The main aim of the experimental investigation was to verify the production performance of feeding mixtures containing dehulled seeds of the two lupin varieties (JUNO and SONET) as a substitute for 50\% of soya extract meal. The resultant feed was administered to young broilers during their growth, i.e. until the age of 40 days. A total of 240 one-day-old broilers (ROSS 308 hybrid combination) were purchased for this experiment. The chickens were reared on deep bedding in an accredited experimental enclosure with controlled light, temperature, zoohygienic and feeding regimens. Rearing conditions fully complied with the requirements of the rearing and feeding of ROSS 308 broilers specified in the respective technological instructions for this kind of broilers. Broilers were divided into three groups, each containing 80 chickens (40 females and 40 males) (i. e. one control group and two experimental groups). The experimental groups (E1 and E2) received feed containing seed of either the JUNO lupin variety or of the SONET lupin variety. The control group (C) was fed on the feeding mixture containing soya extract meal as the major source of protein. The difference between the feeding mixtures used in experimental groups and in the control group was that $50 \%$ of soya extract meal in experimental feeding mixtures was replaced by meal made of dehulled seeds from one of the two lupin seed varieties being tested. Feeding was ensured by plastic tube feeders and hanging watering feeders designed for poultry (Plasson MK II type). Broilers were fed ad libitum with the BR 1 mixture up to the age of 20 days, followed by the BR 2 mixture from Day 21 until Day 40; the experiment was stopped on Day 40. The composition of feeding mixtures is shown in Table 1 . The feeding mixture BR 1 in the control group contained $32 \%$ of soya extract meal, while in experimental groups it contained $16 \%$ of soya extract meal and $16 \%$ of dehulled seeds of the particular lupin variety (JUNO for Group E1 and SONET for Group E2). The feeding mixture BR 2 in the control group contained $28 \%$ of soya extract meal, while in experimental groups it contained $14 \%$ of soya extract meal and $14 \%$ dehulled seeds of one of the two lupin varieties (JUNO for Group E1 and SONET for Group E2). Feeding mixtures were supplemented with minerals and vitamins using the premix ZBCHS Vit. - SK (at a dose of 0.5\%), which also contains enzymes such as 3-phytase, endo-1.4-beta-xylanase, and endo-1.4-betaglucanase. During the experiment, broilers were weighed on Days 1, 10, 20, 30, and 40. Feed conversion, i.e. the consumption of feed per kg of broiler's live weight gain, was calculated. Indicators such as the state of broiler's health, vitality, behaviour, feed intake, water consumption, the quality of droppings and mortality were monitored daily throughout the whole experiment. The results obtained were processed by using mathematical statistical methods implemented using the UNISTAT program. The following statistical parameters were evaluated for each group: arithmetic mean (x) and standard deviation (sd). The differences between average values were evaluated using Student's $t$-test at a significance level of $P>0.05$ (non-significant $-\mathrm{NS}$ ), $P \leq 0.05$ (*), $P \leq 0.01(* *)$.

\section{Results and Discussion}

The results of this experiment have confirmed the suitability of meal made of dehulled lupin seeds as a substitute for soya extract meal in diets designed for young broilers. Based on utility indicators observed in chickens it can be concluded that a $50 \%$ substitution of soya extract meal with meal made of dehulled seeds of the JUNO lupin variety produced no conclusive effect on the production performance of the tested feeding mixtures in contrast to the SONET lupin variety. 
Table 1. Content of nutrients in $\mathrm{g}$ per $\mathrm{kg}$ of the feeding mixture

\begin{tabular}{|l|c|c|c|}
\hline BR 1 & Control & $\begin{array}{c}\text { Experiment E1 } \\
\text { JUNO }\end{array}$ & $\begin{array}{c}\text { Experiment E2 } \\
\text { SONET }\end{array}$ \\
\hline Crude protein ${ }^{1}$ & 228.8 & 241.0 & 222.0 \\
Fat & 63.0 & 70.5 & 70.3 \\
Crude fibre & 29.0 & 20.1 & 19.3 \\
Nitrogen-free extract & 507.5 & 492.8 & 493.9 \\
Crude ash & 64.2 & 61.4 & 60.5 \\
Lysin & 13.5 & 12.7 & 10.4 \\
Methionin & 5.3 & 4.5 & 4.2 \\
Arginin & 14.3 & 19.4 & 13.2 \\
Threonin & 8.5 & 8.5 & 6.7 \\
ME (MJ/kg) & 12.0 & 12.3 & 12.0 \\
\hline BR 2 & Control & Experiment E1 & Experiment E2 \\
& & 222.7 & SONET \\
\hline Crude protein ${ }^{1}$ & 212.0 & 69.8 & 69.7 \\
Fat & 62.4 & 20.1 & 19.3 \\
Crude fibre & 27.8 & 518.9 & 543.7 \\
Nitrogen-free extract & 53.9 & 56.2 & 61.6 \\
Crude ash & 58.7 & 11.3 & 9.4 \\
Lysin & 12.1 & 4.3 & 4.1 \\
Methionin & 5.0 & 18.7 & 13.3 \\
Arginin & 14.2 & 7.6 & 6.0 \\
Threonin & 7.7 & 12.3 & 12.2 \\
ME (MJ/kg) & 12.0 & & \\
\hline
\end{tabular}

${ }^{1}(\mathrm{~N} \times 6.25)$

Table 2. Average live weight of young broilers during the course of their growth

\begin{tabular}{|c|c|c|c|c|c|c|c|c|}
\hline \multirow{2}{*}{$\begin{array}{c}\text { Broilers' } \\
\text { age }\end{array}$} & \multicolumn{2}{|c|}{$\begin{array}{c}\text { Control C } \\
\text { mean }(\mathrm{kg})\end{array}$} & \multicolumn{3}{c|}{$\begin{array}{c}\text { Experiment E1 JUNO } \\
\text { mean }(\mathrm{kg})\end{array}$} & \multicolumn{3}{c|}{$\begin{array}{c}\text { Experiment E2 SONET } \\
\text { mean }(\mathrm{kg})\end{array}$} \\
\cline { 2 - 9 } & $\mathrm{n}=80$ & mean $\pm \mathrm{sd}$ & $\mathrm{n}=80$ & mean $\pm \mathrm{sd}$ & $\mathrm{C}-\mathrm{E} 1$ & $\mathrm{n}=80$ & mean $\pm \mathrm{sd}$ & $\mathrm{C}-\mathrm{E} 2$ \\
\hline Day 10 & 0.189 & \pm 0.0211 & 0.182 & \pm 0.0251 & $\mathrm{NS}$ & 0.181 & \pm 0.0258 & $*$ \\
Day 20 & 0.668 & \pm 0.0616 & 0.660 & \pm 0.0704 & $\mathrm{NS}$ & 0.629 & \pm 0.0699 & $* *$ \\
Day 30 & 1.457 & \pm 0.1222 & 1.428 & \pm 0.1194 & $\mathrm{NS}$ & 1.408 & \pm 0.1175 & $*$ \\
Day 40 & 2.337 & \pm 0.1719 & 2.332 & \pm 0.1638 & $\mathrm{NS}$ & 2.280 & \pm 0.1843 & $*$ \\
\hline
\end{tabular}

NS = non-significant $\quad P \leq 0.01 * * \quad P \leq 0.05 *$

The corresponding results are shown in Table 2. It follows from Table 2 that when $50 \%$ of soya meal was replaced with the product made of dehulled lupin seeds of the JUNO variety (Group E1), the broilers' average live weight remained unaffected during the course of the experiment (Days 10, 20, and 30) and at the end of the experiment (Day 40). In contrast, a 50\% substitution of soya extract meal with the product made of dehulled lupin seeds of the SONET variety decreased the production performance of the feeding mixture. This was manifested by a conclusively lower $(P \leq 0.05)$ live weight of broilers throughout the whole experiment (Days 10 and 30) and at the end of the experimental feeding (Day 40), as compared with the control group (C). On Day 20 the difference in average live weight was tested as highly conclusive $(P \leq 0.01)$. At the end of feeding, i.e. on Day 40, control chickens had an average live weight of $2.337 \mathrm{~kg}$, while those in experimental groups E1 (JUNO) and E2 (SONET) had average live weights of $2.332 \mathrm{~kg}$ and $2.280 \mathrm{~kg}$, respectively. The possibility of replacing soya 
meal has also been confirmed in studies conducted by Koreleski et al. (1987), Roth Maier and Kirchgessner (1994), and Lettner andZollitsch (1995), who showed that the final production performance of feeding mixtures depends strongly on the particular variety used. Most authors came to the conclusion that the optimum content of lupin seeds in the feeding mixtures is up to $20 \%$, which is in accordance with our findings. Higher portions of lupin seeds (i.e. above 20\%) decrease the quality of dropping, feed conversion and utility as documented by Farrell et al. (1999) and RothMaier and Kirchgessner (1994). Variations in the production performance of feeding mixtures based on soya extract meal and dehulled lupin seed can be attributed to the differential levels of nitrogen-containing substances such as essential amino acids. On the basis of our own analyses (related to $100 \%$ dry matter) it was revealed that dehulled seed in the lupin product increases the content of nitrogen-containing substances by approximately $27 \%$. Particularly, in the case of the JUNO variety it increases from $458.9 \mathrm{~g} / \mathrm{kg}$ to $586.3 \mathrm{~g} / \mathrm{kg}$, while in the case of the SONET variety it rises from $331.6 \mathrm{~g} / \mathrm{kg}$ to $422.2 \mathrm{~g} / \mathrm{kg}$. Soya extract meal contains $51.2 \mathrm{~g}$ of nitrogen-containing substances per kg, whereas the product obtained from the JUNO variety by dehulling has a higher portion of nitrogen-containing substances. However, in the case of the product made of the SONET variety the levels of nitrogen-containing substances are lower. The level of nitrogen-containing substances is closely related to the content of essential amino acids. The levels of some of the most important amino acids in soya extract meal and dehulled seeds are as follows: lysine - $31.50 \mathrm{~g} / \mathrm{kg}$ (soya extract meal), $26.12 \mathrm{~g} / \mathrm{kg}$ (dehulled, JUNO), $12.23 \mathrm{~g} / \mathrm{kg}$ (dehulled, SONET), methionine - $7.2 \mathrm{~g} / \mathrm{kg}$ (soya extract meal), $2.13 \mathrm{~g} / \mathrm{kg}$ (dehulled, JUNO), $1.56 \mathrm{~g} / \mathrm{kg}$ (dehulled, SONET), threonine - $20.10 \mathrm{~g} / \mathrm{kg}$ (soya extract meal), $19.50 \mathrm{~g} / \mathrm{kg}$ (dehulled, JUNO), $8.30 \mathrm{~g} / \mathrm{kg}$ (dehulled, SONET), arginine - $37.50 \mathrm{~g} / \mathrm{kg}$ (soya extract meal), $69.5 \mathrm{~g} / \mathrm{kg}$ (dehulled, JUNO), $30.87 \mathrm{~g} / \mathrm{kg}$ (dehulled, SONET). Analogous differences were detected for other amino acids. It follows from the results of our analyses that lysine and sulphur-containing amino acids, particularly methionine, are the most critical amino acids in lupin seeds, as concluded from the results of analyses reported by Gualtieri and Rapaccini (1990), and RothMaier and Kirchgessner (1993). Deficiencies in these amino acids can be corrected by supplementing feeding mixtures with synthetic amino acids, as reported by Perez-Alba et al. (1990).

The nutritional and dietetic value of lupin seeds, which increases as a result of dehulling is discussed by Smulikowska et al. (1995), Annison et al. (1996), Rubio et al. (1998), Gdala (1998), Rubio et al. (2003), and Mieczkowska et al. (2005). The spectrum of amino acids in lupin seeds (i. e. Lupinus genus) is characterised by a high content of arginine. This finding was also confirmed in our laboratory by the analysis of a large number of different lupin varieties. In this respect lupin seed can be considered as a significant source of this particular essential amino acid. The above-mentioned authors have reported that dehulling decreases the levels of non-starch saccharides, while the digestibility of both ileal dry matter and other nutrients present in feed, including the metabolised energy that can be utilised in poultry, increases. Yellow varieties of lupins, which also include the JUNO variety tested in our experiment, are particularly promising with regard to the nutrition of monogastric animals and particularly poultry because they have already been used in feeding mixtures for chickens, as reported by Teixiera and Dos (1995), Mieczkowska et al. (2005) and RothMaier and Paulicks (2003). The above-mentioned values of live weight were obtained from chickens having the following consumption of feed per $\mathrm{kg}$ of live weight gain on Day 40: $1.89 \mathrm{~kg}$ in the control group, $1.85 \mathrm{~kg}$ in Group E1 (JUNO) and $1.93 \mathrm{~kg}$ in Group E2 (SONET). Feed consumption per chicken at the above-mentioned feed conversion during the course of the experiment was as follows: $4.417 \mathrm{~kg}$ in the control group, $4.314 \mathrm{~kg}$ in the experimental group E1 (JUNO) and $4.401 \mathrm{~kg}$ in the experimental group E2 (SONET). The results of feed conversion and feed consumption are shown in Table 3. It follows from 
Table 3. Feed consumption and feed conversion throughout the experiment

\begin{tabular}{|l|c|c|c|c|c|c|}
\hline \multirow{2}{*}{ Day } & \multicolumn{3}{|c|}{$\begin{array}{c}\text { Feed conversion } \\
(\mathrm{kg})\end{array}$} & \multicolumn{2}{c|}{$\begin{array}{c}\text { Feed consumption } \\
(\mathrm{kg})\end{array}$} \\
\cline { 2 - 7 } & Days 1 - 10 & Days 1 - 20 & Days 1 - 30 & Days 1 - 40 & broiler/40days & broiler/day \\
\hline $\begin{array}{l}\text { Control } \\
\text { Experiment }\end{array}$ & 1.61 & 1.53 & 1.69 & 1.89 & 4.417 & 0.110 \\
$\begin{array}{l}\text { E1 JUNO } \\
\text { Experiment }\end{array}$ & 1.62 & 1.54 & 1.69 & 1.85 & 4.314 & 0.108 \\
E2 SONET & 1.61 & 1.70 & 1.74 & 1.93 & 4.401 & 0.110 \\
\hline
\end{tabular}

the results obtained that the lowest conversion and the lowest consumption of the respective feeding mixture in chickens was observed when soya extract meal was replaced with dehulled seed of the JUNO lupin variety. Although feed consumption in chickens in the experimental group E2 (SONET) for 40 days was lower $(4.401 \mathrm{~kg})$ than that in the control group (4.417 $\mathrm{kg}$ ), feed conversion in this group was higher. In order to enhance the digestibility of nutrients, feeding mixtures were supplemented with the following enzymes: 3-phytase (EC 3.1.3.8), endo-1,4-beta-xylanase (EC 3.2.1.8) and endo-1,4-beta-glucanase (EC 3.2.1.4) by using the premix ZBCHS Vit. - SK. The importance of supplementing feeds based on lupin seeds with these enzymes is pointed out by Mieczkowska et al. (2004), Kocher et al. (2000), and by Gdala (1998). Although Antoniewicz et al. (1992) has found an enhanced availability of phosphorus in lupin seeds as compared with legumes such as field bean (Vicia faba), the use of phytase in feeding mixtures fed to broilers is substantiated.

Another positive finding of this experiment is that broilers in both experimental groups were in excellent health and showed no clinical symptoms of any disease. Zero mortality was found in experimental chickens during growth, and only one chicken died in the control group $(0.80 \%)$. It is obvious that the excellent state of the broilers' health also reflects the ideal conditions in the experimental enclosure, which differ from the respective operational conditions in agricultural practice.

\section{Testace dvou odrůd semen lupiny jako náhrady sojového extrahovaného šrotu ve vegetabilních dietách pro výkrm kuřat}

Cílem experimentu bylo ověřit vhodnost použití dvou polských odrůd odslupkovaných semen lupin, nízkoproteinový SONET a vysokoproteinové JUNO jako vhodné proteinové komponenty do krmných směsí určených pro výkrm brojlerových kuřat, jako $50 \%$ náhrady sojového extrahovaného šrotu. Výsledky experimentu dokládají, že vhodným ošetřením lupinového semene (odslupkováním) lze významně zvýšit jeho nutriční hodnotu. Odslupkováním lze získat produkt (jádro) s vy̌̌ším obsahem dusíkatých látek o 27 \% ve srovnání se semenem, které lze použít jako vhodnou proteinovou komponentu do krmných směsí, určenou k výkrmu kuřat. Produkční účinnost, jak dokumentují výsledky experimentu, je dána použitou odrůdou lupiny. Vykrmovaná kuřata ve 40. dnu výkrmu u odrůdy JUNO (skupina P1) dosáhla živé hmotnosti 2,332 kg, srovnatelné s kuřaty kontrolní skupiny (K) $2.337 \mathrm{~kg}$, na rozdíl od odrůdy SONET (skupina P2), u které dosáhla kuřata průkazně $(P \leq 0.05)$ nižší průměrnou hmotnost $2,280 \mathrm{~kg}$. Tuto průměrnou živou hmotnost dosáhla kuřata při spotřebě krmné směsi na $1 \mathrm{~kg}$ přírůstku živé hmotnosti $1,89 \mathrm{~kg}$ (K), $1.85 \mathrm{~kg}(\mathrm{P} 1)$ a $1.93 \mathrm{~kg}$ (P2). Výsledky potvrzují vhodnost náhrady sojového extrahovaného šrotu odslupkovanými semeny lupin. Při sestavování krmných směsí je však nutné znát přesně živinové složení použité odrůdy. Za významné z hlediska výživy lze považovat poznatek, že semena rodu Lupinus jsou významným zdrojem aminokyseliny argininu, která je v krmných směsích pro drůbež často deficitní. 


\section{Acknowledgements}

This research was carried out within the framework of the Research Plan of the Ministry of Education, Youth and Physical Training of the Czech Republic MSM6215712402 "Veterinary Aspects of Food Safety and Quality."

\section{References}

ANNISON G, HUGHES RJ, CHOCT M 1996: Effects of enzyme supplementation on the nutritive value of dehulled lupins. Brit Poultry Sci 37: 157-172

ANTONIEWICZ A, DUMANSKA K, OMBACH A 1992: Availability of phosphorus from field bean (Vicia faba) and lupin (Lupinus albus) seeds to broiler chickens. J Anim Feed Sci 1: 127-137

BRENES A, SLOMINSKI BA, MARQUARDT RR, GUENTER W, VIVEROS A 2003: Effect of enzyme addition on the digestibilities of cell wall polysacharides and oligosacharides from whole, dehulled, and ethanol-extracted white lupins in chickens. Poultry Sci 82: 1716- 1725

FARRELL DJ, PEREZ-MALDONADO RA, MANNION PF 1999: Optimum inclusion of field peas, faba beans, chick peas and sweet lupins in poultry diets. II. Broiler experiments. Brit Poultry Sci 40: 674-680

GDALA J 1998: Composition, properties, and nutritive value of dietary fibre of legume seeds. A review. J Anim Feed Sci 7: 131- 149

GUALTIERI M, RAPACCINI 1990: Possibilities and limitations of using white sweet lupin in the feeding of broiler chickens. 59: 53-57

KOCHER A, CHOCT M, HUGHES RJ, BROZ J 2000: Effect of food enzymes on utilisation of lupin carbohydrates by broilers. Brit Poultry Sci 41: 75-82

KORELESKI J, RYS R, KUBICZ M 1987: Seeds of new domestic varieties of lupin, pea and soyabean in diets for table chickens and rats. Rozc Nauk Zoot Mon Rozpr 25: 221-244

LETTNER F, ZOLLITSCH W 1995: Lupins in broiler feeds. Forderungsdienst 43: 285-288

MIECZKOWSKA A, SMULIKOWSKA S, NGUYEN CV 2004: Effect of enzyme supplementation of white lupin (Lupinus albus var. Butan) - containing diets on performance, nutrient digestibility, viscosity, $\mathrm{pH}$, and passage rate of digesta in broiler chickens. J Anim Feed Sci 13: 475-486

MIECZKOWSKA A, JANSMAN AJM, KWAKKEL RP, SMULIKOWSKA S 2005: Effect of dehulling and alpha-galactosidase supplement on the ileal digestibility of yellow lupin based diets in broiler chickens and adult roosters. J Anim Feed Sci 14: 297-304

PEREZ-ALBA LM, DIAZ-ARCA L, CEJAS-MOLINA MA, PEREZ-HERNANDEZ M 1990: Improving protein quality of maize-lupin diets with synthetic amino acids. Arch Zootec 39: 85-93

RAVINDRAN V, TABE LM, MOLVIG L, HIGGINS TJV, BRYDEN WL 2002: Nutritional evaluation of transgenic high-methionine lupins ( Lupinus angustifolius L) with broiler chickens. J Sci Food Agric 82: 280-285

ROTHMAIER DA, KIRCHGESSNER M 1993: Composition and nutritive value of various white and yellow lupin varieties (Lupinus-Albus L and Lupinus-Luteus L) for pigs and poultry. Agribiol Res 46: 218-228

ROTHMAIER DA, KIRCHGESSNER M 1994: White lupins (Lupinus-Albus L) as a replacement for soybeanmeal in diets for fattening chickens. Arch Geflügelkd 58: 111-114

ROTHMAIER DA, KIRCHGESSNER M 1995: Feeding of high proportions of freshly harvested or stored white lupins (Lupinus albus L) and enzyme supplements to fattening chickens. Arch Geflügelkd 59: 108- 111

ROTHMAIER DA, PAULICKS BR 2003: Feeding and nutritional value of sweet blue and yellow lupin seed (Lupinus angustifolius L., Lupinus luteus L.) for broiler chicks. Arch Geflügelkd 67: 175- 178

RUBIO LA, BRENES A, SETIEN I, DE LA ASUNCION G, DURAN N, CUTULI MT 1998: Lactobacilli counts in crop, ileum and caecum of growing broiler chickens fed on practical diets containing whole or dehulled sweet lupin (Lupinus angustifolius) seed meal. Brit Poultry Sci 39: 354-359

RUBIO LA, BRENES A, CENTENO C 2003: Effects of feeding growing broiler chickens with practical diets containing sweet lupin (Lupinus angustifolius) seed meal. Brit Poultry Sci 44: 391-397

SMULIKOWSKA S, WASILEWKO J, MIECZKOWSKA A 1995: A note on the chemical composition of the cotyledons and seed coat of three species of sweet lupin. J Anim Feed Sci 4: 69-76

STEENFELDT S, GONZÁLEZ E, KNUDSEN KEB 2003: Effects of inclusion with blue lupins (Lupinus angustifolius) in broiler diets and enzyme supplementation on production performance, digestibility and dietary AME content. Anim Feed Sci Technol 110: 185-200

TEIXEIRA AS, DOS R 1995: Replacement of soyabeans by lupins ( Lupinus luteus) in the feeding of broiler fowls. Rev Port Cienc Vet 90: 20-28

UZIĘBŁO L, GULEWICZ K, TARASEWICZ Z, BEDNARCZYK M, SZCZERBIŃSKA D, LIGOCKI M 1996: Effect of lupin alkaloid fractions level on performance and blood parameters in chickens. J Anim Feed Sci 5: 261-271 